\title{
INFINITIVES IN THE 1820 SETTLER LETTERS OF DENUNCIATION: WHAT CAN A CONTEXTUALISED APPLICATION OF CORPUS-BASED RESULTS TELL US ABOUT THE EXPRESSION OF PERSUASION?
}

\author{
MATYLDA WŁODARCZYK \\ Adam Mickiewicz University, Poznań \\ wmatylda@ifa.amu.edu.pl
}

\begin{abstract}
This paper takes issue with Biber's (1988) findings concerning the significance of infinitives for what he calls the "overt expression of persuasion" (Biber 1988: 115). It aims to demonstrate that statistically generated results of research on large electronic corpora of contemporary English may not be verifiable in small, well-contextualised, single-genre collections, such as the one representing 19th century English used in this study. The collection comprises denunciation letters addressed to the colonial authorities (the Colonial Office) by the first British settlers in the Cape Colony (the 1820 Settlers). The letters follow the generic model of petition (Włodarczyk 2010) understood as an official written request. An act of denunciation, as we may assume, contributes to the inherent persuasiveness of petitions by increasing the illocutionary force (in the sense of Searle 1969, 1979) of the letter. Therefore, patterns of distribution of infinitives as markers of persuasion (Biber 1988) are particularly interesting to trace in the 1820 Settler denunciation letters. The paper shows that some of Biber's statements may not be taken as valid generalizations, as the persuasive potential of infinitives may not be corroborated unless each and every token is thoroughly contextualized. Furthermore, an analysis of requests in denunciations conducted within Speech Act Theory (Austin 1962; Searle 1969; Blum-Kulka 1984; Culpeper and Archer 2008) shows that it is first and foremost politeness concerns (cf. Brown and Levinson 1987), not the increased need for persuasiveness, that determine the degree of the illocutionary force of requests.
\end{abstract}

KEYWORDS: Petition; memorial; denunciation; overt persuasion; infinitives; South African English.

\section{Introduction}

The analysed data come from the South African National Archives in Cape Town which house ample evidence pertaining to the 1820 British settlement of the Cape of Good Hope. The evidence is drawn from five volumes of files containing official settler letters to the Colonial Office in the first years of the settlement (1820-1825). Constituting a window on a range of social, political and practical aspects of the colonisation, the cor- 
respondence is also a linguist's treasury allowing insights into the modes and patterns of communication in the early stages of the development of English in South Africa. Still, the early 1820 Settler letters have so far failed to receive sufficient attention from linguists (but cf. Mesthrie and West 1995).

In line with genre ${ }^{1}$ theory, it may be demonstrated that genres are sensitive to the effects of social upheaval or transformation, ${ }^{2}$ and migration in particular (e.g. Kerswill 2006). Włodarczyk (2010) presents a move analysis of the pre-colonial and colonial petitions (cf. Swales 1981, 1990; Biber et al. 2007) and shows that the latter exhibit new structural and pragmatic patterns. Apart from these constructional and functional shifts, another new phenomenon may be noticed in the colonial petition: a number of letters of denunciation ${ }^{3}$ can be found in the analysed body of data. Although denunciations are marginal in the surviving collection of letters, an attempt at accounting for their emergence is in order.

As the externally defined function of the texts under scrutiny is persuasive, the study aims to establish whether Biber's (1988) claim as to the persuasive nature of infinitives is verifiable in a small collection of texts. In his groundbreaking analysis of written and spoken genres of English, Biber (1988) singled out seven textual dimensions. Dimension 4, the "Overt expression of persuasion", is defined by the features "associated with the speaker's expression of own point of view or with argumentative styles intended to persuade the addressee" (Biber 1988: 115). Factor analyses conducted by Biber identified infinitives, prediction and necessity modals, suasive verbs, split auxiliaries and conditional subordination as the positive features of this dimension (1988: 111). According to the statistical procedure adopted by Biber, infinitives constituted the most salient positive loading for "Overt persuasion" (1988: 90). Therefore, the infinitives are viewed as the most appropriate investigation focus in a paper pursuing the linguistic correlates of the persuasive functions of the analysed texts.

\footnotetext{
${ }^{1}$ The term is not problematised here for lack of space. Cf. e.g. Devitt (2004) for an excellent and comprehensive discussion.

${ }^{2}$ More recently Swales, based on a selection of literature on genre from the last decade, pointed out that the current perspective involves a "greater sense that genres and genre sets are always evolving in response to various exigencies" (Swales 2009: 5).

${ }^{3}$ The term denunciation is not a very fortunate one. It is used in this paper, however, following the terminology established in a body of research on accusatory practices over the last two decades (cf. Fitzpatrick and Gellately 1996; Joshi 2003). Most probably, the contributions in German and other research investigating the practice in the Third Reich and the German Democratic Republic (cf. the references in Gellately 1996) popularized the English cognate of the Latin borrowing. Consequently, terms such as whistle-blowing (euphemistic; applied widely in research on ethics), squealing, tale-telling or ratting (colloquial) are dismissed as inappropriate. Interestingly, both in German and Russian, the term has only received pejorative connotations as a result of historical developments (cf. Kozlov 1996; Joshi 2003). The French lexicon, for example, which most writers on denunciation take note of, provides a valuable set of distinctions of accusatory practices, defining denunciation alongside delation and deposition (cf. e.g. Lucas 1996).

${ }^{4}$ In his later work (Biber 1995), the term "Overt expression of argumentation" is used to describe this dimension.
} 
Biber's multidimensional analysis ${ }^{5}$ (henceforth MD) referred to above is an approach designed specifically to deal with texts, text-types and registers (for Biber, these are synonymous with genres), rather than with individual linguistics constructions (Biber et al. 2007: 261). Its general aim is to present a feature-based comparison of spoken and written registers. As Biber himself claims in his later work, although "the dimensions were identified from analysis of a general corpus of spoken and written texts, they can be applied to the description of more restricted discourse domains" (Biber 2006: 179). The analysis of a single genre undertaken in this paper is considered to be one such discourse domain. Moreover, like Biber's, the present study has an empirical approach, but unlike Biber's, its scope is narrow in terms of the focus on a single genre and a small amount of data.

MD analysis has presented an extremely robust methodological perspective (cf. e.g. an overview in Biber 2006: 180) and Biber's findings were also followed in studies involving genre development and change. For example, Westin (2002), who studied modifications of newspaper editorials over time, accepts Biber's findings regarding the persuasive/argumentative function of infinitives and claims that the increase in the frequency of use of this feature in her data over time indicates growing persuasiveness of the genre (Westin 2002: 104). Geisler (2003), who observes a reverse tendency for the nineteenth-century personal letter (women's letters in particular are found to have become less persuasive), also analyses the frequencies of Biber's features marking the persuasive/argumentative dimension of language use. When conducting corpus-based studies, Westin (2002) and Geisler (2003) may be more justified in their decisions to apply Biber's findings than the present study. Still, the generalisation as to the persuasive/argumentative function of the infinitives (Biber 1988: 111) has not yet been verified for a small-scale synchronic investigation into a well-contextualised genre.

The paper is structured as follows. It begins by placing the study within the context of research into nineteenth century English and historical genre studies (Section 1.1). Next, a brief account of the historical background of the 1820 settlement is given. Then, the letters selected for analysis are presented in a broader perspective of socio-historical research into denunciation and accusatory practices (Section 2 and subsections). Some arguments are presented for the validity of pursuing the investigation into the 1820 Settlers' denunciations despite the very limited scale of the phenomenon. In the course of the discussion, the concept of denunciation is defined in more detail and the denunciation letter is placed within the genre conventions of petition. In the following sections, the view of persuasion adopted in the paper is described (Section 3). Persuasion reveals its multifaceted nature, and difficulties emerge in capturing its linguistic correlates.

\footnotetext{
5 "New" MD analysis of the discourse domain of university language was introduced in 2001 (published as Biber 2006). Here, Biber develops a typology of infinitives based on controlling verbs and acknowledges that these might determine the differences in function of to-clauses (e.g. Biber 2006: 219; cf. also Biber et al. 1999: 699-710). Still, the sweeping generalisations made in his first MD work (1988) have never been modified or amended explicitly.
} 
Then, an analysis of the persuasive nature of infinitives based on some implications drawn from Biber (1988) is conducted (Section 4 and subsections). The analysis is supplemented with an investigation into the structurally and functionally-determined use of infinitives within the genre of petition (Section 4.2.2). The analysis applies Speech Act Theory (Austin 1962; Searle 1969; Blum-Kulka and Olshtain 1984) and draws on Politeness Theory (Brown and Levinson 1987). The concluding section points out the problems connected with the application of corpus-based findings to small wellcontextualised text collections.

\subsection{Aspects of research into 19th century English}

While a range of studies devoted to 19th century English exist (see Kytö et al. 2006 for an overview), many terrains are still unexplored. Areas such as the development of early extraterritorial Englishes, the language of lower social classes or developments pertaining to specific genres deserve a comprehensive investigation, and a range of structural aspects of early stages of Englishes around the world remain understudied. Lacunae in description include regional and social diversity concerning pronunciation, morphology and syntax as well as externally induced language change. A sociohistorical perspective, which is central to this paper, has so far not been applied to many varieties of 19th century English (Fitzmaurice and Minkova 2008: 8). A number of reasons can be identified for this neglect, one of them being the lack of comprehensive databases (corpora of texts) facilitating historical investigation into synchronic and diachronic aspects of language change which would account for the heterogeneity of English of the time. Corpora such as ARCHER (A Representative Corpus of Historical English Registers), Corpus of Late Modern English Prose (18611919) or CONCE (Corpus of Nineteenth Century English), though broad in scope, include only some 19 th century material. ${ }^{6}$ One other limitation they have in common is that on their basis researchers are only able to provide descriptions of upper class or standard English local to the British Isles.

Records of the language of lower social strata in the 19th century and the Englishes of the speakers of early colonial varieties are not as easily accessed. The lack of easily accessible data is a result both of placing the focus on standard and well-educated informants and of historical circumstances. Either way, it results in the need to, as Beal (2008) puts it, "make the best use of "bad data",? In this vein, Dollinger (2008: 357) tackles the data problem while investigating the use of modals in historical Canadian

\footnotetext{
${ }^{6}$ Corpus of Late Modern English Prose (1861-1919) does not cover the first half of the nineteenth century and samples standard language only. The CONCE (Corpus of Nineteenth Century English) corpus, which is the only linguistic database devoted entirely to the period, despite its wide genre coverage (e.g. the corpus also includes letters), has a gap between 1830-1850.

${ }^{7}$ This echoes Lass (1990). Cf. also Włodarczyk (2004).
} 
English and proposes: "a heuristic method to overcome, at least in part and as an approximation, (a) the lack of readily-available data, (b) low token discourse frequencies and (c) genre-specific variation that makes the characterization of linguistic variables within national varieties a particular challenge". Convincing as Dollinger's argument might be in shedding some light on the direction of development of modal usage on the conservative-non-conservative cline in Early Ontario English, not all of his heuristics (i.e. "methods of discovery, which may include empirical, analytical and speculative methods", as defined by volume editors, Fitzmaurice and Minkova 2008: 9) are readily acceptable. Although the present study may not avoid making significant "shortcuts to answers to research questions that would otherwise be years, if not decades, away" (Dollinger 2008: 358), in that its reasoning is based on a limited amount of data, we are ready to proceed with the investigation rather than resort to using immediately accessible but merely satisfactory material. In other words, rather than follow the heuristics proposed by Dollinger (2008), ${ }^{8}$ an attempt is made to stick to the best available archival manuscript evidence, despite its acute scarcity. This is in line with what has recently been advocated as taking greater note of the "texts 'below' the surface of printed language" (Elspass 2007: 4) and the necessity to provide language histories from below (cf. Elspass et al. 2007). One implication of the writing of such histories is incorporating data from the lower social strata, such as the petition letters (Elspass 2007: 5) analysed in this study.

\subsection{Genre frameworks}

The data under analysis constitute a record of official correspondence, i.e. the texts fall within the extremely broad and diversified category of letter-writing. With growing literacy, this communicative activity gained currency in the Early Modern period and became routine in private and official interaction for many social strata over time (cf. e.g. Barton 2000 et al. 2008; Nevala and Palander-Collin 2005; Elspass et al. 2007; Nurmi and Palander-Collin 2008). Recently, interest in letters as mirrors of linguistic and social change has increased significantly. ${ }^{9}$ For the social, interactional and linguistic interface, the studies based on the social networks ${ }^{10}$ approach utilize letters as invaluable

\footnotetext{
${ }^{8}$ In brief, this involves assuming parallel developments in a colonial variety and British English for which much more comprehensive databases are available.

${ }^{9}$ Cf. e.g. Nevalainen and Raumolin-Brunberg (2003) for some initial work on the Corpus of the Early English Correspondence, the special issues of the Journal of Historical Pragmatics (2004; published also as Nevalainen and Tanskanen 2007) and the European Journal of English Studies (2005), as well as the most recent developments (Nurmi et al. 2009). Also van Bergen and Denison (2007) provide a description of an 18th century letter collection released as an electronic corpus in 2003.

${ }^{10}$ This approach is utilized in a comprehensive project called The Codifiers and the English Language undertaken at Leiden University by Tieken-Boon van Ostade and a group of fellow researchers, (cf. $<$ http://www.hum.leiden.edu/lucl/codifiers/results/results.html $>$ for the list of recent publications). A signifi-
} 
study material (cf. e.g. Beal 2008 for an overview of corpora containing Late Modern letters). Single genre corpora compiled from letters illustrate both their appeal and significance for historical linguistics (cf. Dossena and Tieken-Boon van Ostade 2008). Although the historical descriptions of letter-writing are clearly biased towards the personal letter as a more immediate reflection of what has recently been referred to as the "language of daily life" (Nurmi et al. 2009; cf. the analysis proposing language histories "from below" in Elspass et al. 2007), there is no denying the fact that the official letters may be equally worthy of study. In fact, as van Bergen and Denison (2007: 233) show for the Corpus of 18th Century Prose, in many cases, differentiating between personal and business correspondence is impossible and unnecessary. ${ }^{11}$ Similarly, even though the official authorities, rather than relatives or friends, are the addressees in the 1820 Settler correspondence analysed in this study, some nonstandard forms may occur. ${ }^{12}$

The substantial body of research referred to above illustrates the debatable generic integrity of letters and the need to view this as an umbrella term rather than a definite generic category. Clearly, a more restricted characterization is needed in order to capture the textual frameworks of the 1820 Settler correspondence. To this end, we follow the approach proposed by Bazerman (1995: 81) who views the users' recognitions and attributions of a given genre as its underlying foundation. The meta-references most frequently found in the data are memorial, petition, memorialist and petitioner. As far as petitions ${ }^{13}$ are concerned, a clear delimitation of the genre is also problematic. For instance, Bergs (2004) proposes a socio-pragmatic typology of letters in which requests are considered a subtype of petition, defined as an appellative text addressed by a social inferior to a social superior. Though such a definition is acceptable from the perspective of this study, its focus falls more on genre change as a reflection of language change. Therefore, its aim is placing the analysed texts within a specific generic tradition rather than defining the collection as representing a clearly-delimited genre. For our purposes, petition may be understood as an official written request directed at some authorities aiming at redressing an injustice or grievance held by its author/authors.

Research conducted so far (Włodarczyk 2010) has shown that the analysed documents continue the practice of petitioning, which goes back at least to Early Modern English society. In Britain, in the 18th century, individuals and groups exercised their

cant amount of data for the project is drawn from letters. A project based on Dutch letters (Letters as loot) is currently in progress at Leiden University.

${ }^{11}$ But cf. Dossena and Tieken-Boon van Ostade (2008) who point out the complexity of the personal/nonstandard and colloquial interface.

${ }^{12}$ The other collection of letters consulted later in this study, the 1820 Settler applications for the Cape of Good Hope Settlement Scheme (1819), is even more diversified in this respect.

${ }^{13}$ Memorial is another term used to refer to the analysed genre. The term is also a frequent metareference in the 1820 Settler correspondence. Knights (2005: 124) uses this name only to discuss one specific instance of a collective petition, the so-called "Legion Memorial". Many of his primary sources, however, contain the term in the title. For the sake of consistency, petition is used in this paper, although the two terms are interchangeable. 
civil rights and participated in the processes of social transformation by means of petitions (cf. e.g. Knights 2005). Petitions were a way to voice opinions on the powers of different authorities and might have involved demands of changes in legislation. In the Cape Colony, petitions worked mostly as a way of settling individual grievances, but they were also used as a means of collective protest against the colonial authorities. A collective petition (1823, cf. Hockly 1948: 100) to the metropolitan government signed by the most prominent Settlers ultimately resulted in removing the autocratic Governor Charles Somerset from office in 1826. As a tool of civil rights and power, petitions fulfilled an important function in fostering the relationship between citizens and the state.

\subsection{Data selection procedure}

The 1820 Settler petitions in the South African archives consist of several thousand letters covering the first years of the settlement (1820-1825). The letters involve a range of official matters such as the distribution of the grants of land and food ratios or the issuing of permits to leave or enter the colony. The initial selection procedure was generally random with an aim of creating a corpus containing a more or less equal number of letters for each respective year. The overall number of letters included in the corpus approximates three hundred comprising ca. 50,000 words. ${ }^{14}$ A close reading of the selected letters allowed filtering some 30 items containing an accusatory move defined as the naming of a perpetrator of an offence suffered by the author or directly requesting legal action against them, such as e.g. "I have to request that such steps may be taken against them as the Law in Criminal Cases directs" (J.T. Erith). The number of individual authors of such letters was smaller and multiple letters from one author were excluded, so finally 20 letters comprising ca. 7,000 words were selected for analysis. ${ }^{15}$

One further collection of petitions, similar in structure and function, was consulted in an attempt to find more background information on the practices of denunciation among the 1820 Settlers. The collection comprised ca. 800 letters of application for the Settlement Scheme written by the settler candidates in Britain in 1819. The process of application for the colonial settlement scheme was in writing only and received an immense response of 80,000-90,000 letters within a couple of months (although estimates vary in this respect). Given the scale of response and the eagerness to emigrate, the application itself might be seen as a competitive activity prompting candidates to resort to different types of persuasive strategies to ensure their success. Still, accusatory practices which might potentially eliminate competitive applicants are at best exceptional in this collection. A single letter which could be qualified as denunciatory was located (Mortimer, Thomas B.). Although this finding provides nothing but negative evidence, it is

\footnotetext{
${ }^{14}$ The corpus is presently under construction and its final word count is hard to specify at this stage.

${ }^{15}$ The justification for pursuing the study into denunciation despite the limited number of letters was presented in Section 1.1.
} 
relevant to the present study for two reasons. Firstly, it shows that denunciation practices were not widespread among the settler candidates and their appearance among the 1820 Settlers is unlikely to be traced back to metropolitan models. Secondly, it opens the possibility of viewing the colonial petition as a transforming genre. For these reasons, the occurrence of denunciation, though marginal, is even more striking in a functionally homogeneous collection of the colonial petition.

\subsection{Settlers and denunciation}

The 1820 Settlers were a group of ca. 4,500 British immigrants brought to the Cape Colony in 1819-1820 as part of the settlement plan designed by the British government. The settlers were located around the Grahamstown military headquarters in the Eastern Cape. The initial stage of the colonisation was a time of hardship for the newcomers, who were unprepared for the rough weather conditions and incompetent at the farming business to which they were employed. Hence, they frequently addressed petitions to the local government seeking assistance and issuing complaints on a wide range of matters. In their petitions, statements of an accusatory nature are to be found. For instance, settlers inform the Colonial Office of the ill-conduct of their Party leaders (Seton), ship agents (Willson), their own spouses (Jane Smith), local government officials (Hockly, J.T. Erith, Martinson) and fellow settlers (Watson, Anon). They sometimes call for punishment for the perpetrators (Anon) or at least demand an explanation (Willson). Some petitioners (Bailie, Watson) level accusations in response to allegations made against them. In a single case, a settler denounces himself for drunkenness and physical assault on his wife (John Smith). In general, petitioners state their own agendas quite openly by requesting help in solving their problems. One denunciation, written by an anonymous author, is exceptional in this respect as it appears to forward concerns for the well-being of the Settler community and the work of the local government. Allegedly, as the denouncer claims, a fellow settler earning his living as petition writer for the incompetent "by fine words increases to a great length" (Anon) both the volume and gravity of minor offences in order to make financial gain. The petitioner thus feels obliged to warn the Colonial Office not to waste their precious time on this kind of barratry. Naturally, malicious motives and hidden agendas can not be excluded in any of the cases. These are, however, beyond the scope of this study.

\section{Denunciation - a definition of a letter of denunciation}

Denunciation is defined as reporting to some authorities that somebody is involved in an unlawful or otherwise harmful activity (cf. Fitzpatrick and Gellately 1996). ${ }^{16}$ The

\footnotetext{
${ }^{16}$ As Joshi notes, the definition drawn from Fitzpatrick and Gellately (1996: 747) - "spontaneous communications from individual citizens to the state (or to another authority such as the church) containing accusa-
} 
denouncer is usually personally affected by the consequences of this activity and tends to have a clear personal agenda. In the analysed data, the idea of denunciation is extended to cover individual or collective grievances reporting on ill-treatment or injustice inflicted by an individual. Typically, denunciation letters involve a request for a specific action from the Colonial Office. Therefore, their nature is inherently persuasive, as their authors make "attempts to either change the thinking or behavior of an audience, or to strengthen its beliefs, should the audience already agree" (Virtanen and Halmari 2005: 3 ; italics original).

\subsection{Denunciation in history}

A few issues raised by social historians need to be mentioned in order to provide a background for the study of denunciation in the Cape Colony. As researchers in the field have established, denunciation bears universal appeal for ordinary people and is part and parcel of periods of social turmoil (Joshi 2003; Williams 2001). Even though the practice has mostly been studied in the context of dictatorships, it has been more common than one would expect and quite widespread in divergent circumstances such as democratic countries (cf. McCarthyism in the US; the Weimar Republic in Germany; Joshi 2003: 11). It was totalitarian regimes, however, that turned denunciation into an ideological tool, encouraging and frequently publicizing denunciatory practices and as a result producing ample and fascinating material for research. Thus Stalinist Russia (e.g. Fitzpatrick 1996) and Nazi Germany (e.g. Gellately 1997) have received the greatest attention from researchers, the latter mostly since the fall of the Berlin Wall. To mention some further denunciation contexts: France (Williams 2001) or the French Basque Country under German occupation (Ott 2006) have also been investigated by social historians.

\subsection{Nondenunciatory ${ }^{17}$ England?}

As Fitzpatrick and Gellately (1996: 747) have noted, an investigation into the practices of accusation in English-speaking societies is hindered from the very start, as such activities "are not clearly distinguished as a category of everyday behavior in contemporary English". As students of denunciation practices in Stalin's Russia and Nazi Germany, respectively, Fitzpatrick and Gellately further claim that the English term does not reflect the concept (as they understand it) accurately and that it has an exotic feel. This may suggest that accusatory practices of this kind are alien to British society.

tions of wrong doing by other citizens or officials and implicitly or explicitly calling for punishment" - has been adopted by many (Joshi 2003: 8; cf. also Joshi's references).

${ }^{17}$ This term comes from Fitzpatrick and Gellately (1996: 762). 
British social historians are not eager to take the practice of denunciation under scrutiny, although they willingly investigate the custom of petitioning over the centuries (e.g. Zaret 1999; Knights 2005; Patterson 1993; How 2003). Despite the popular opinion that in modern Britain, unlike some other European states such as Germany or France, "societal tradition is more skeptical of state power and more inclined to fear its abuse, and denunciation tends to be discouraged" (Fitzpatrick and Gellately 1996: 759), the English Reformation (Shagan 2003), the Restoration period and the early 18th century (Brant 2004) saw the development of denunciation practices on a considerable scale (Tobias 1979). Furthermore, as in all known instances of the witch-hunting, the English witches of, for example, the 17 th century were frequently objects of denunciation.

\subsection{Denunciation models in the Cape Colony}

In the context of the 1820 settlement of the Cape of Good Hope, two issues need to be stressed. Firstly, unlike the majority of the above-mentioned cases, the analysed material was not publicized by printing (although the petitions addressed at the metropolitan government were discussed by the Parliament and parliamentary debates were disseminated by the press ${ }^{18}$ ). Consequently, the 1820 petitioners were not exposed to accusatory practices or models, not to mention denunciation writing instructions. The amount of exposure to instances of denunciation or letter-writing instructions may be impossible to verify, and, unlike letter-writing manuals, instructions for denouncers are not plausible in this context. Secondly, the scale of denunciation practices was very limited, which renders attempts at clarifying the status of denunciation and its social perception very difficult. Bearing in mind, however, that petitions serve as a vehicle for denunciations, the background of the former may be significant for the latter.

\subsection{Aspects of the political context of the petition}

Research shows a major role for printed petitions in the invention of public opinion in later Stuart England, in the shaping of a citizen-based representation, as well as a vehicle of public opinion (Knights 2005). This tradition was continued into the 19th century. The colonial expansion, however, gave rise to a totally new social and political organization. It is important to emphasise that the 1820 Settlers participated in "an ill-planned and ill-conducted enterprise", local rule was "an arbitrary system of government, and its natural consequences - abuse of power by local functionaries, monopolies, restrictions, etc." (Mirror of the Literature, Amusement and Instruction... 25: 717, May 1835).

\footnotetext{
${ }^{18}$ Parliamentary Debates was founded in 1803 and taken over by Thomas Hansard in 1809, renamed Hansard in 1822.
} 
Clearly, the political organisation of the settlement in terms of civil rights and representation was a step backwards from the metropolitan system. In this new diluted system of political representation, the colonial context deprived the petition of its power and effectiveness in forcing public or individual opinion. This situation bears some resemblance to the feudal procedure of petitioning as described by Patterson (1993: 60). Even though the right of appeal by means of petitions was assigned to the powerless, as she states, their petitions were mostly unsatisfactory as "there was no law that required a petition to be granted" (Patterson 1993: 61). Bearing in mind the autocratic rule of governor Somerset in the Cape Colony and his complacency, if not neglect, towards the 1820 Settlers, one may claim that the practice of petitioning was likely to undergo a serious crisis in the colonial situation. On the content level, we have noticed the introduction of accusatory statements into the petition. Denunciation might have been a way of reinforcing the effect of the request made in petitions in a situation where social injustice was rarely redressed. The breach of civil loyalty involved in a denunciation might have been a way to emphasise government loyalty as a pay-off to the petition addressees. On the textual level, there may have been a range of manifestations of this crisis. It is therefore interesting to see whether the above-mentioned developments might have fostered new generic conventions involving an increased expression of linguistic persuasion such as (as we may assume from Biber 1988) the use of infinitives.

\subsection{Denunciation vs. petition vs. complaint}

Despite the highly formulaic character, and their construction around the core move of request, the 1820 Settler petitions included other speech acts such as apologies, expressions of gratitude and complaints. Still, an official request of personal significance to the petitioner, or one made in the name of a group of petitioners, remained the central function. However, in the case of extended complaints involving an accusation, the author's main aim appeared to be instigating an official action against the alleged perpetrator rather than settling his grievance (cf. the case of the anonymous letter referred to above). Therefore, denunciations stand out among the 1820 Settler petitions.

The distinction between denunciation and complaint is difficult to make, not only in the case of the 1820 Settler correspondence. Joshi (2003: 11) notices that "[in] the Ancien Régime, the practice of writing letters of complaint called lettres de cachet had a denunciatory character" and, moreover, observes that these letters functioned as attempts at redressing an injustice, similar to the British genre of petition. Fitzpatrick (1996) also struggles with the distinction between denunciation and complaint in her analysis of Stalinist denunciations. She claims that complaints are more focused on the injury to the writer, while in denunciations it is on the act of wrongdoing by another person (Fitzpatrick 1996: 845). In a more general perspective, Fitzpatrick and Gellately (1996: 758-759) point out that the latter do not carry a social stigma attached to the former. The present paper does not aim to establish a clear-cut delimitation of denuncia- 
tion letters on the grounds of content, social perception or motivation, which are of lesser significance here than the transformations of the genre indicated by the introduction of accusatory practices into the petition. Thus, formally, the letters which may be classified as denunciations may be understood by the authors above as intermediate between complaints and denunciations. As Devitt (2004: 8) states, "[t]he particular labels that scholars give to genres will vary for different scholarly purposes".

\section{Persuasion}

Needless to say, persuasion crosses disciplinary boundaries in the humanities (cf. Noy 2002: 279-280). It is rather unusual to find such unanimity of opinion when it comes to the definition of a concept, especially among linguists of different persuasions. Cognitivists (Kamalski et al. 2008), a linguistic pragmatist and historian (Virtanen and Halmari 2005: 3), a gender expert (Lakoff 1981) and communication specialists (Simons et al. 2001: 7) all agree that persuasion involves attempts to change (or reinforce) the attitudes of its addressees. One other aspect of persuasion which is likely to be taken for granted is the fact that it is by nature covert or realized implicitly (Östman 2009: 199). For example, in discussing an instance of the process of discourse transformation over time, which he calls the technologisation of discourse, Fairclough (2003: 80) notes that "persuasion is certainly a significant speech function, but in a mainly covert form which anticipates substantial inferential work on the part of the reader". He further emphasises the covert nature of persuasion in the analysed text ${ }^{19}$ which "is designed to persuade while appearing to be merely informative" (Fairclough 2003: 80). One may claim that the reverse is likely to be true for the genre of petition. The frequent meta-reference to the generic frame of petition and the outspokenness of the authors in setting their own agendas result in letters which are unlikely to conceal their core message or jeopardize the authors' intent.

Even though, as the research mentioned above shows, persuasion is more often than not implicit, the analysed data are likely to illustrate the opposite and less common, overt kind of attempts to change or reinforce the attitudes of the addressees. As stated above (Section 1), "overt persuasion" is one of the descriptive dimensions of English texts provided by Biber's (1988; cf. also Biber 1999) statistical study. Biber's research has shown a correlation of this dimension with the frequency of occurrence of infinitives, which motivates choosing this linguistic feature as the focus of this investigation. The main question pertaining to persuasion is whether infinitives, as Biber (1988) claims, are used as overt markers of persuasion in the 1820 Settlers' denunciation letters. Secondly, the paper proposes linking the overt expression of persuasion to the scale of directness proposed by Speech Act Analysis (Austin 1962; Searle 1969; Blum-Kulka

\footnotetext{
${ }^{19}$ The genre under scrutiny is academic prospectuses analysed within the framework of Critical Discourse Analysis.
} 
1984; Culpeper and Archer 2008). In other words, if overt and non-implicit persuasion is indeed favoured in the petition, the central functional move of request should be realized by means of direct, explicit strategies. If this is indeed the case, the link between the overt expression of persuasion and an increased illocutionary force of the request communicated by means of petitions may be confirmed. Prior to addressing these questions, the genre framework and its possible constraints regarding the expression of persuasion need to be discussed.

\subsection{Genre-related constraints}

A range of genre conventions apply to petition, and some of these may affect the expression of persuasion. It must be stressed that petitioning is a subscriptional genre (Knights 2005), with a request featuring as its major functional element. A textual constraint may be formulated at this point: it is within the move of request, which is the core functional constituent of petition (cf. a Swalesian analysis in Włodarczyk 2010; cf. Swales 1981, 1990), that the linguistic means of persuasion are most likely to cluster. Requests, however, according to Speech Act Theory (Austin 1962; Blum-Kulka and Olshtain 1984), involve an imposition which tends to be minimised by means of the language of humility (Zaret 1999; How 2003) in petition. Here, a social constraint is of ultimate importance: in our case, it is the social inferior addressing the social superior (cf. e.g. Bergs 2004). Petitions, therefore, utilize a range of polite strategies used to address, show appreciation and esteem for the "patron to be". As the addressees of petitions are in power to act in order to change the existing state of affairs according to the wishes of petitioners, the requests of the latter need to be both persuasive and attentive of the (face) needs (in the sense of Brown and Levinson 1987) of the former. It is further claimed that petitions, designed to obtain a certain result (beneficial to the author), are highly unlikely to conceal the core message; therefore, (at least some of) their means of persuasion are overt. The communicative action taken by the petitioners, moreover, fulfills the sincerity condition (in the understanding of Searle 1969), i.e. the data attest authentic requests of real people whose complaints are not imaginary and whose wishes are genuine. On the whole, it may be assumed that petitioners are guided by a real motivation to construct an effective (i.e. persuasive) request.

\section{Methodology and discussion: Infinitives}

According to Biber (1988: 111), infinitives are the most salient markers ${ }^{20}$ of overt persuasion (cf. Westin 2002). This is particularly the case, he further maintains, when they

\footnotetext{
${ }^{20}$ Biber also mentions prediction and necessity modals, suasive verbs and conditional subordination which were not well represented in the analysed letters.
} 
are headed by attitudinal adjectives or verbs encoding a speaker's point of view on the content of the infinitival clause (e.g. happy to do it; hope to see it). So, as Biber suggests, infinitives may be overtly persuasive under some syntactic (i.e. verbal or adjectival heads) and semantic (i.e. encoding of a speaker's point of view) conditions. An analysis of infinitives occurring in petitions offers an opportunity to verify Biber's results against a small, well-contextualised corpus of texts.

Firstly, it is worth noting whether the syntactic properties of the heads of infinitival clauses pointed out by Biber feature in our data, i.e. whether as, he claims, it is the infinitives with verbal and adjectival heads that are overtly persuasive. Although Biber fails to acknowledge this fact, apart from the verbal and adjectival heads, infinitives may also be headed by nouns: ${ }^{21}$ such a clause is referred to as the infinitival relative clause (IRC; e.g. a man to fix the sink). It may also be instructive to look at the statistical distribution of the three types of heads in order to verify Biber's statement as to the syntactic conditions placed on infinitives as markers of overt persuasion.

Secondly, the semantic constraint pointed out by Biber needs to be verified: the infinitives need to be checked with respect to the attitude/point of view element. As it is frequently difficult to establish this on the basis of the raw infinitive (i.e. head and infinitive), Biber's syntactic and semantic constraints are verified with relation to their immediate context ( 10 words to the left of the infinitival to and 10 to the right). Given that the dimension of overt persuasion as described by Biber is a result of a complex statistical procedure applied to a corpus of nearly one million words, it is assumed that following it may not be sufficient to verify the persuasive function of infinitives in a small, generically homogeneous corpus. Thus, the obtained results are presented and discussed as background for further analysis described below.

To begin this analysis, following the generic constraints referred to above (Section 3.1), a syntactic constraint is introduced on the assumption that the agent/experiencer of the main clause needs to be identical to the author, as it is his/her/their own agenda that is pursued in the petition (as in (1) below). In other words, this thematic role would have to be occupied by an author-referential pronoun. This would mostly be the pronoun $I$, or, in the case of some (more traditional) petitions in which the authors refer to themselves as Your petitioner(s)/memorialist(s), (as in (2) below), by the 3rdperson singular (or plural in the case of collective petitions) pronouns ${ }^{22}$ or a noun naming the author. Before the constraint is actually introduced, the presence of 1 st person pronouns in the vicinity of the to introducing an infinitival clause needs to be investigated (10 words to the right and left). This analysis shows that in $61 \%$ of the infinitival clauses the author reference was expressed by means of the above-mentioned pronouns in the immediate context of the infinitival clause, so the application of the constraint was further justified. Still, a range of instances were found in which it was the addressee that occu-

\footnotetext{
${ }^{21}$ Some syntacticians may disagree on the head status of the noun in this type of clause (cf. Bhatt 2006).

${ }^{22}$ Expressions such as Your petitioner(s)/memorialist $(s)$ and the referent pronouns (3rd person singular and plural) correspond to $I$ in the more traditional structure of the petition.
} 
pied the agent/experiencer thematic role of the infinitival head. These were also marked as persuasive as in (3) below.

(1) I found it absolutely necefsary to memorialize Your Excellency (J.T. Erith)

(2) your Memorialist is ready and willing to make the most Sacred Oath (Honey)

(3) I hope your Excellency will take my sake into consideration to grant me a Pass (Martinson)

The cases in which it was neither the author nor the addressee to fulfill the thematic role discussed above were marked as other and regarded as unlikely to carry overt expression of persuasion as in (4) below.

(4) Mr Parker ... greatly hurries to prejudge the question (Seton)

The next step in the analysis is the description of the infinitives with respect to their position in the structural organization of the petition. Some infinitives occur in the opening and closing formulae in fixed phrases. These are excluded from the analysis on the grounds of their formulaic character and because these elements are more likely to be skipped (or taken for granted) by the readers. This observation may prompt another step in the analysis: it is very likely that fixed expressions (involving infinitives) may not be viewed on a par with regular infinitival clauses; therefore, they are assigned to a separate category. Further discussion of the analysis is preceded by the results of the application of Biber's syntactic and semantic head constraints and presented in the sections 4.2.1 and 4.2.2 below.

\subsection{Infinitives and Biber's syntactic and semantic head constraints}

The application of Biber's syntactic head constraint yielded the results presented in Table 1 below. In the total number of 164 items, there is a single instance of a headless (parenthetical clause) which needs to be excluded from analysis, leaving 163 heads for analysis. As Table 3 below shows, verbal heads are most frequent (57\%); adjectival heads, however, are not too common (17\%). Infinitival relative clauses - which Biber fails to mention in his description of overt persuasion marked by infinitives - are hardly immaterial, as they account for $26 \%$ of all head tokens. Moreover, some of these express the author's point of view and involve an attempt to change the attitudes of the addressee as in (5) below.

$$
\text { my desire or Intention to set up a demand or claim (Willson) }
$$

As the example above and Table 1 below show, the expression of persuasion is not, as may be conluded from Biber's argument (1988), limited to the infinitives headed by 
verbs or adjectives, but infinitival relative clauses may also reflect author's attitudes and point of view by means of which they might attempt to influence the addressee's stance.

Table 1. Biber's syntactic head constraint.

\begin{tabular}{lcc}
\hline Head type & Number & $\%$ \\
\hline V (verbal head) & 92 & $57 \%$ \\
IRC (infinitival relative clause) & 43 & $26 \%$ \\
A (adjectival head) & 28 & $17 \%$ \\
\hline
\end{tabular}

Biber's suggestion regarding the semantic features of heads (expressions of attitude or point of view) is hard to formalize. Hence, all decisions as to the persuasive potential of heads under analysis are fairly intuitive. It is therefore fitting to describe the applied procedure in more detail. Prior to the presentation of the results of the semantic analysis, the procedure is illustrated on the basis of the most frequent head tokens. Table 2 presents the 21 most frequent head tokens lemmatized according to the meaning of the stem. These account for ca. $57 \%$ of all heads, the remaining tokens occurring twice (over 7\%) or once (ca. 36\%). Even though a decontextualised semantic analysis of raw heads is impossible, we may venture a guess that some tokens are more likely to be persuasive than others (marked with Persuasive). This may be assumed of the items denoting the expression of request, intention or attempt (order, beg, apply, endevour, intending); ability, (lack of) permission and (lack of) possibility (able, permission, power, impossible, refuse); insistence (determination), causation (induce); necessity (necessary). ${ }^{23}$ These 13 items represent $31.28 \%$ of all the head tokens. As for the remaining 8 items, their persuasive potential is less obvious. The high frequency tokens pleased, honor, obliged and the less common bound occur in fixed expressions, some of which are wellestablished in the structure of the genre, i.e. the opening and closing formulae (marked as Formulae in the table). This observation suggests that these items enjoy special status, constitute $14.11 \%$ of all the heads and may not be viewed without reference to the formulaic aspects of the analysed letters (cf. Section 4.2.2 below). The two remaining most frequent items are verbs be and have whose functional and semantic scope is much wider than that of regular lexical tokens. Good and leave are not function words, but they are extremely frequent and their persuasive potential is hard to establish at face value. To conclude the semantic analysis of the most frequent infinitival heads, we need to state that it allowed filtering 4 (11.65\% of the total) items, which do not exhibit evident persuasive potential.

\footnotetext{
${ }^{23}$ In line with Biber's suggestion, verbs of saying, opinion and point of view are included in the analysis of the remaining heads.
} 
Table 1. Most frequent head tokens.

\begin{tabular}{lccl}
\hline Word & Freq. & $\%$ & Semantic association \\
\hline HONOR & 8 & 4.91 & Formulae \\
PLEASED & 8 & 4.91 & Formulae \\
HAVE & 7 & 4.29 & $?$ \\
ABLE & 6 & 3.68 & Persuasive \\
BE & 6 & 3.68 & $?$ \\
OBLIGED & 6 & 3.68 & Persuasive \\
ORDER & 6 & 3.68 & Persuasive \\
POWER & 5 & 3.07 & Persuasive \\
BEG & 4 & 2.45 & Formulae \\
IMPOISIBLE & 4 & 2.45 & Persuasive \\
APPLY & 3 & 1.84 & Persuasive \\
BOUND & 3 & 1.84 & Formulae \\
DETERMINATION & 3 & 1.84 & Persuasive \\
ENDEVOUR & 3 & 1.84 & Persuasive \\
GOOD & 3 & 1.84 & $?$ \\
INDUCE & 3 & 1.84 & Persuasive \\
INTEND & 3 & 1.84 & Persuasive \\
LEAVE & 3 & 1.84 & $?$ \\
NECEISARY & 3 & 1.84 & Persuasive \\
PERMIT & 3 & 1.84 & Persuasive \\
REFUSE & 3 & 1.84 & Persuasive \\
\hline & & & \\
\hline & 3 & & \\
\hline
\end{tabular}

The application of the procedure described above rendered the following results for the total number of heads (Table 3 ). The items with the greatest persuasive potential constitute nearly half of all the heads. The items whose meaning is unlikely to render them persuasive accounts for over one third of the total. Obviously, the analysis of raw items needs to be confirmed in context.

Table 2. Biber's semantic head constraint.

\begin{tabular}{lcc}
\hline Semantic association & Number & \% of all heads \\
\hline Fixed tokens & 23 & 14.11 \\
Persuasion & 76 & 46.63 \\
$?$ & 64 & 39.25 \\
\hline Total & 163 & 100.00 \\
\hline
\end{tabular}




\subsection{A contextualisation of Biber's constraints}

Even a cursory glance at the contextualized infinitival clauses in relation to Biber's semantic constraint poses serious problems. In order to illustrate these, instances with be (dubious persuasive potential; examples 6-11) ${ }^{24}$ and order (strong persuasive potential; examples 12-17) are presented below.

(6) you Sir will have the Goodnefs to inform me what Legal Proceedings I $\operatorname{am}^{25}$ to persue (J.T.Erith)

(7) it is against my wish to intrude on Your Lordships time (Jane Erith)

(8) their grants of land in the new Settlement are to be regarded in a different light (Martinson)

(9) my Wife and Children were to have come on board (J.T. Erith1)

(10) they are to draw the same (Willson)

(11) I was to have distributed (Bailie)

The infinitives headed by the verb to be are found in a fixed expression to be to (3 cases). The remaining ones are indeed unlikely to be markers of persuasion, as none of the quotes above involves an attempt at changing the attitude of the addressee. Please note that to sustain this claim for example (6), wider context is provided. So far, indeed, 5 out of 6 dubious persuasive heads turn out to be correctly indicated for elimination as a result of the constraints formulated on the basis of Biber (1988).

A closer look at the potentially persuasive order (examples below), however, reveals some problems. Except for the final example (17), the persuasive function of infinitival clauses is no longer as clear as it appeared in the semantic description of raw heads. As we can see in the examples below, order is unlikely to contribute to the persuasiveness of the letter. In (12), order does not involve a speech act directed at the addressee of the letter ( 15 is similar in terms of the role of the addressee, though order is a noun here). In (13), the author is the experiencer of the passivised verb as well as the target of the illocutionary point of the reported speech act. Although in (14), the order (as a noun) is framed in a request, the illocutionary point of the speech act realized as "I ... request that you will do me the favour" (cf. 17 for a similar case) rather than by means of order.

(12) [I] ordered the Sergeant delivering goods to tell $\mathrm{M}^{\mathrm{r}}$ Dawson (Hockly)

(13) I was ordered to wait on Col Cuyler (Hockly)

\footnotetext{
${ }^{24}$ As an anonymous $P S i C L$ reviewer points out, examples 6 and 7 are commissive speech acts expressing volition.

${ }^{25}$ From example 6 on, bold-faced items are heads of infinitival clauses, the infinitives are underlined.
} 
(14) I owe to her and to myself to request that you will do me the favor of an open order ... for $\mathrm{M}^{\mathrm{rs}}$..Willson ... to be landed there (Willson)

(15) the contemptible Orders which Your Lordship was pleased to Transmit for him to fulfill (Jane Erith)

(16) I yet hour waited on Col Cuyler to request in respectfull terms his order to prepare to Quit the Colony (Hockly)

(17) Your Lordship will be pleased to order $\mathrm{M}^{\mathrm{r}}$ Denyson to terminate the protracted Businefs (Jane Erith)

To summarise, the results of the analysis applying Biber's syntactic and semantic constraints suggest that as much as it may be applicable to raw heads, its results are not verifiable against the contextualized infinitival clauses. Discrepancies of a similar sort are likely to occur should the contextualization be taken further. This shows that the analysed material does not allow generalizations like the ones suggested by Biber (1988; i.e. that it is verbal and adjectival heads of infinitival clauses expressing point of view or opinion that are most likely to be persuasive) as these claims lack explanatory potential if individual instances require a contextualized verification in every single case. The only implication drawn from the above analysis concerns fixed phrases and the need to view these as a separate category. This argument is taken further in Section 4.2.2 devoted to the correlation of infinitives and the structural organization of the petition.

\subsubsection{Infinitives and the theta-role constraint}

Examples (1-3) above illustrated the overlap of the author/addressee with the thematic role of agent/experiencer of the infinitival clauses under consideration. Example (4) above gives an instance of a different referent in a clause which is highly unlikely to be overtly persuasive. The distribution of referents (author, addressee and other) and this thematic role are presented in Table 4.

Table 3. The theta-role constraint.

\begin{tabular}{lcc}
\hline Referent & Number & $\%$ \\
\hline Author & 100 & $62 \%$ \\
Addressee & 45 & $27 \%$ \\
Other & 18 & $11 \%$ \\
\hline
\end{tabular}


Indeed, one of the generic constraints of the petition is that its author pursues his/her/their own agenda in the letter. Thus, the most frequent referent of the agent/experiencer of the head of the infinitival clause is the author (62\%). The addressee fulfills this thematic role in nearly one third of all head tokens, while $11 \%$ of the cases have other referents.

A contextualization of this constraint reveals the following problematic cases.

(18) we shall probably have to leave five dear infant children unprotected (J.T. Erith)

(19) The next Morn ${ }^{\mathrm{g}}$ I repaired to Port Elizabeth to endevour to purchase a few tools (Hockly)

(20) I have therefore to entreat Your Lordship will be pleased to order $\mathrm{M}^{\mathrm{r}}$ Denyson to terminate the protracted Businefs (Jane Erith)

In these examples, the underlined infinitives show that even the 1st-person (author) agents and experiencers in the infinitival heads may not render the phrase overtly persuasive. For instance, in (18), even though the author is the agent, no persuasive content is overt. Thus, some further conditions need to be applied: infinitives need a specific type of head. This takes us back to the semantic constraint (Biber 1988), whose application failed to produce useful general findings.

\subsubsection{Infinitives and structure}

As the application of three different constraints on raw and narrowly contextualized heads discussed above failed to provide satisfactory conclusions, let us now proceed to considering the issue of persuasiveness of infinitives in relation to the structure of the petition. A more detailed model of structural and functional organisation of the petition was presented on another occasion (Włodarczyk 2010). The study involved conducting a Swalesian move analysis (Swales 1981, 1990) based on the claim that moves are "semantic and functional units of texts that have specific communicative purposes" (Biber et al. 2007: 36). It established that petitions comprise a range of obligatory and optional elements, of which the openings, closings and the core request move constitute the frame of the genre and are hardly ever omitted. Therefore, it is these elements then that are selected for a structure and function based analysis of infinitives in denunciation letters.

In the following analysis, a great degree of attention is devoted to the request move, viewed from the perspective of Speech Act Theory (Austin 1962; Searle 1969; BlumKulka and Olshtain 1984). As the core functional elements of the petition (and denunciation) letter, requests are most likely to be the locus of persuasion. At the same time, however, a conflicting need may be introduced by this intrinsically fact-threatening 
speech act: in a genre phrased in the language of humility, a face-threat calls for mitigation. The amount of redressive strategies is, moreover, likely to be relatively high, due to the fact that the threat is undertaken by a social inferior and targeted at a social superior. Thus, the request becomes a ground of contest between the effectiveness of the act and the status-bound politeness-demands concerning the genre. Bearing in mind that infinitives constitute manifestations of overt persuasion, while politeness considerations are more likely to favour non-explicit strategies of request-making, a preference for the former may be predicted for the analysed denunciations. This prediction is possible on the assumption that the introduction of an accusatory move into the petition aims to strengthen the effectiveness of the request. In order to corroborate the prediction, an analysis of infinitives and imposition minimisers needs to be conducted for the request moves (Section 4.3 below).

\subsubsection{Fixed phrases - openings and closings}

As pointed out several times above, a range of fixed phrases containing infinitival clauses occur in the petition. These require a separate discussion as they may not be viewed on a par with other items, due to the different processing demands imposed on the addressees. Moreover, formulaic items cluster quite consistently in the openings and closings which, in turn, are very specific elements of the structure due to their framing and boundary marking functions (examples 21-23 are openings, 24-25 are closings).

(21) I must beg to afsure you that I am (Willson)

(22) I also beg to state (Ellis)

(23) I had the honour to receive (Seton)

(24) I have the honor to be (Eliza Cryle, Anon, Willson closing)

(25) your Memorialist will ever feel himself in duty bound to pray (Watson)

In the 20 analysed letters, 9 closings and 5 openings of formulaic character were observed. The share this number constitutes in the total of the infinitives under analysis is not substantial (just over 8\%). Because of the discourse organization function of fixed expressions (Wray 2002: 97), they are unlikely to be the locus of overt persuasion. The reader is unlikely to devote to them the attention that is required to render them effectively persuasive, for two reasons: firstly, on the basis of the above-mentioned results, it could be claimed that they are well-established in genre structure. Clustering in openings and closings, they become, to an extent, predictable, and they are not likely to contribute new content, so they may pass unnoticed as redundant. Secondly, they are easier to process than novel sequences, so even if they are spotted, they are unlikely to receive as much attention as novel forms. 
This brief account of fixed expressions with infinitival clauses provides another piece of evidence that a contextualisation (also a structure-based one) is essential in the analysis of linguistic correlates of overt persuasion, while generalizations, such as those drawn from Biber (1988), are not very useful.

\subsection{The request move}

An analysis of requests as core functional elements of petition is inconceivable without reference to Speech Act Theory (Austin 1962; Searle 1969). Firstly, when making a request, speakers clearly undertake action by means of language. Secondly, this methodological approach has recently produced revealing insights, presented in a range of historical investigations (e.g. Arnovick 1999; Kohnen 2007 and 2008; Taavitsainen and Jucker 2007; Culpeper and Archer 2008). Most importantly, as Taavitsainen and Jucker (2008: 10) state, "speech act analysis could serve as a ground-breaker towards a pragmatic history of the English language".

According to some scholars, speech acts pattern clearly with functionally defined text-types (Bergs 2004; Kohnen 2008). Kohnen (2008) provides a useful guide to the tracing of the specific patterns of speech acts in historical texts. Starting with a specific genre and its functional profile, we may predict what types of speech acts are most likely to occur (Kohnen 2008: 276). For petitions, for instance, which are designed to forward the wishes or grievances of their authors to the official authorities, request is the most natural speech act to feature. In historical speech act analysis, which largely follows the traditional Searlian (1969) typology, requests are usually understood as a type of directive (e.g. Kohnen 2008; Culpeper and Archer 2008). In his definition of directives, Searle (1969: 65; original italics) states that " $[\mathrm{t}] \mathrm{o}$ request, ask, order, entrear, enjoin, pray or command (that A be done) counts as an expression of a wish or desire (that A be done)". But our understanding of a request, unlike Searle's, excludes orders and commands due to the social distance between the author and the addressee (cf. Section 3.1). Requests and orders/commands may have the same illocutionary point ${ }^{26}$ (i.e. to make the hearer do something) but they differ in the degree of illocutionary force, as Searle notes elsewhere (1979: 3). Such a distinction is in line with Bergs's (2004) formal and functional typology of letters based on different speech acts. Although the three broad functional types proposed by Bergs (descriptive, expressive and apellative) include a category determined by a great incidence of directives (the apellative type), an internal socio-pragmatic division into requests (made by socially inferior to superior) and orders/commands (given by socially superior to inferior) is of crucial importance to this paper.

To sum up, requests are seen here as a specific type of directive speech act (Searle 1969) which aims to cause a specific action on the part of the receivers. Having defined

\footnotetext{
${ }^{26}$ An illocutionary point is defined as a point or purpose of a given locution type (Searle 1979: 3).
} 
the unit of analysis, we still need to delimit it clearly. To this end, we may assume, in line with Kohnen (2008: 298), that requests "are not expressed by units larger than a sentence or a clause", as in (26) and (27) below (note that the latter example does not contain an infinitive).

(26) I hope your Excellency will take my sake into consideration, to grant me a Pass, to my distressed Wife and Children (Martinson)

(27) I doubt not but you will have it adjusted as from the Calamity I have Suffered and more recent disappointments I am really in want of it (Cryle)

The analysis of requests presented below follows a speech act analysis coding scheme ${ }^{27}$ as presented in Blum-Kulka and Olshtain (1984; cf. also Warga 2004). As the categorization is derived from a corpus of contemporary spoken language (collected by means of written questionnaires, however), not all of the categories are applicable to the analysis of written requests. Furthermore, the categorization may not be accepted uncritically for historical texts, as Culpeper and Archer (2008) have shown; thus, some room for modification must be allowed.

Requests, as Blum-Kulka and Olshtain (1984) show, may be realized by means of three major types of strategies, placed on a scale of directness. The most direct requests are phrased explicitly as imperatives, performatives or hedged performatives (BlumKulka and Olshtain 1984: 201), such as Do it, I'm asking you to do it, I'd like you to do $i t^{28}$ (type 1). Indirect speech acts (according to Searle 1979) such as could/would you do $i t$ are employed as conventionally indirect strategies (type 2). A variety of strategies are placed on the nonconventional indirect level, including fragmentary or contextual reference, such as Why is the window open? or It's cold in here (type 3). Blum-Kulka and Olshtain (1984: 202) distinguish 9 more specific strategies, of which only 5 are to be found in the analysed data (cf. Table 6 below). These include: explicit performatives, hedged performatives, scope stating (I really wish you'd stop bothering me), reference to preparatory conditions (Would you mind moving your car please?) and mild hints (I'm a nun in response to a persistent boy). The first three strategies may be understood as direct (also referred to as impositives), the strategy involving reference to preparatory conditions as conventionally indirect, while the last strategy as nonconventionally indirect. As the notion of directness and its historical scope are fraught with problems, it is

\footnotetext{
${ }^{27}$ The scheme was initially devised for the CCSARP project (Cross-cultural Speech Act Realisation Patterns), comprising requests and apologies in the following languages/varieties: Australian, American and British English, Canadian French, Danish, German, Hebrew and Russian. It has been revised over time and subject to various modifications by individual authors.

${ }^{28}$ As Culpeper and Archer (2008: 63) notice, the Locution derivable (you'll have to do something) and Scope stating strategies (described as Obligation statements and Want statements respectively in later work on CCSARP I wish you'd stop; Blum-Kulka and Olshtain 1984: 202) are technically also Searle's indirect speech acts of assertion. Nevertherless, they are more direct than the conventional indirect speech acts, e.g. How about cleaning up?
} 
important to underline that we follow the thinking of Culpeper and Archer (2008: 56) who see it as " the explicitness with which the illocutionary point is signaled by the utterance".

The choices made by speakers with respect to the level of directness are determined by social motivations and the degree to which speakers wish to minimise the imposition inherent in the act of making a request. This, however, is not the only way to control the force of the face-threatening act. Syntactic downgraders, such as the interrogative form, negation (I wonder if you wouldn't mind...), the use of past tense (I wanted to ask for...') or an embedded if-clause (I'd appreciate it if you left me alone) may be employed to mitigate the imposition. Among these, only interrogatives do not function as syntactic downtoners in the requests under consideration. Speakers may also decide to use a range of other softening means, such as consultative devices (do you think), understaters (could you tidy up a bit), hedges (It would really help if you did something about the kitchen) and downtoners (e.g. perhaps). Of these, only hedges and downtoners are represented in our data (Table 6 below).

Further modifications may be placed outside the "Head act", as Blum-Kulka and Olshtain (1984) refer to the minimal unit constituting a request in the "Adjunct to Head act". These include: checking on availability (Are you going in the direction of the town? And if so, is it possible to join you?), getting a precommitment (Will you do me a favour? Could you perhaps lend me your notes for a few days?), grounders (I missed class yesterday, could I borrow your notes?), sweeteners (You have beautiful handwriting, would it be possible for me to borrow your notes?), disarmers (Excuse me, I hope you don't think I'm being forward, but is there any chance of a lift home?) and cost minimisers (Pardon me, but could you give me a lift, if you're going my way?). As Table 6 shows, only grounders, sweeteners and disarmers were found in the analysed data. Also, the list of downtoners occurring in Adjuncts to Head act needs to be extended to capture conventionalized promises of gratitude, such as in (28) below.

$$
\text { your Memorialist will ever feel himself in duty bound to pray (Watson) }
$$

Except for the choices referred to above, the speaker is also free to adopt a specific point of view which, in Blum-Kulka and Olshtain's understanding (1984: 203), may either emphasise the perspective of the speaker (Do you think I could borrow your notes?) or of the hearer (Could you tidy up the kitchen?). Alternatively, requests may be both speaker and hearer-oriented (So could we please clean up?) or impersonal (It might not be a bad idea to get it cleaned up?). As far as our data is concerned, only the mutual we perspective fails to occur. To illustrate the application of the coding scheme adopted from Blum-Kulka and Olshtain (1984; cf. also Warga 2004), a request, classified as an indirect one, (26) is analysed below as (29).

(29) I hope your Excellency will take my sake into consideration, to grant me a Pass, to my distressed Wife and Children (Martinson) 


\begin{tabular}{lll}
\hline Dimension & Category & Element \\
\hline Address term & None & your Excellency \\
Request perspective & Hearer-oriented & your Excellency will \\
Request strategy & Scope stating & I hope \\
Downgraders & Preparator & your Excellency will take my sake into... \\
Adjuncts to Head Act & None & none \\
\hline
\end{tabular}

The number of requests in individual texts and the number of infinitives occurring in them is presented in Table 5. Three letters do not contain the request moves and are, therefore, excluded from the analysis. The number of infinitives per request varies from 1 to 5 . Only three requests do not contain infinitives. Overall, 31 infinitives occur in 22 requests found in 17 letters.

Table 4. Infinitives in requests.

\begin{tabular}{lccc}
\hline $\begin{array}{l}\text { Source } \\
\text { (N=20, ca.7 000 words) }\end{array}$ & $\begin{array}{c}\text { All Inf tokens/ } \\
100 \text { words }\end{array}$ & $\begin{array}{c}\text { Requests } \\
(\mathrm{N}=22)\end{array}$ & $\begin{array}{c}\text { Inf in requests } \\
(\mathrm{N}=31)\end{array}$ \\
\hline CO 223_Powell & 0.68 & 1 & - \\
CO 158_f215_Smith & 0.80 & - & - \\
WCO_136_ElizaCryle & 0.96 & - & - \\
CO 136_f43_Seton & 1.30 & 2 & $1+1^{30}$ \\
CO 136_f54_Bailie & 1.46 & - & - \\
CO 201_f60_Whittle & 1.46 & 1 & 1 \\
WCO_158_f209_JaneSmith & 1.51 & 1 & 2 \\
CO 201_Buckley & 1.53 & 1 & 1 \\
CO 178_f36_Watson & 1.64 & 2 & $0+3$ \\
CO 136_fx_ParkerParty & 1.71 & 1 & 5 \\
CO 158_f30_JTErith_1 & 1.80 & 1 & 1 \\
CO 201_f9_anon & 2.20 & 2 & 2 \\
CO 178_f65_Honey & 2.31 & 1 & - \\
CO 136_f70_Hockly & 2.41 & 2 & - \\
CO 178_f44_Ellis & 2.44 & 2 & 2 \\
CO 136_f51_Whiley & 2.92 & 1 & 2 \\
CO 249_JTErith & 3.14 & 1 & 1 \\
CO 158_f59_Martinson & 3.17 & 1 & 3 \\
CO 136_f42_Willson_2 & 4.97 & 1 & 3 \\
wCO 249_JErith & 5.08 & 1 & \\
\hline
\end{tabular}

${ }^{29}$ The coding follows the National Archives of South Africa volume references: CO stands for material pertaining to the Colonial Office in Cape Town, it is followed by the folio number in a given volume. Volumes are arranged chronologically: CO 136-1820, CO 158-1821, CO 178 - 1822, CO $201-1823$, CO 223 1824 , CO $249-1825$. Women's letters are marked with $w$.

${ }^{30}$ If two requests occur in one letter, the numbers of infinitives for the respective requests are marked with.+ 
Table 6 presents the findings of the analysis. As can be seen, the majority of the requests (19) use the direct, performative strategies, accompanied by hedging and other mitigating strategies, 2 use indirect strategies and one utilizes a nonconventionally indirect strategy of Mild hint. This finding is in line with the assumption that the overt expression of persuasion, determined by some genre conventions of the petition (cf. Section 3.1), is likely to correlate with the direct strategies of speech act realization. ${ }^{31}$

Table 5. Speech act sequential analysis of requests.

\begin{tabular}{|c|c|c|}
\hline \multicolumn{3}{|l|}{ REQUEST STRATEGIES } \\
\hline \multirow[t]{4}{*}{ Degree of imposition/explicitness } & Direct & 19 \\
\hline & Indirect & 2 \\
\hline & Nonconventionally indirect & 1 \\
\hline & TOTAL & 22 \\
\hline \multirow[t]{6}{*}{ Request strategy } & Explicit performatives & 7 \\
\hline & Hedged performatives & 7 \\
\hline & Scope stating & 5 \\
\hline & Reference to preparatory conditions & 2 \\
\hline & Mild hint & 1 \\
\hline & TOTAL & 22 \\
\hline \multirow[t]{4}{*}{ Request perspective } & Hearer-oriented & 15 \\
\hline & Speaker-oriented & 3 \\
\hline & Impersonal & 4 \\
\hline & TOTAL & 22 \\
\hline \multicolumn{3}{|l|}{ OPTIONAL STRATEGIES } \\
\hline \multicolumn{3}{|l|}{ Syntactic downgraders } \\
\hline & Negation & 1 \\
\hline & Past tense & 3 \\
\hline & Embedded if & 1 \\
\hline \multirow[t]{2}{*}{ Other downgraders } & Hedges & 10 \\
\hline & Downtoners & 7 \\
\hline \multirow[t]{4}{*}{ Adjuncts } & Grounder & 9 \\
\hline & Sweetener & 3 \\
\hline & Disarmer & 6 \\
\hline & Reward (payoff) & 5 \\
\hline
\end{tabular}

\footnotetext{
${ }^{31}$ One needs to bear in mind, however, that the most direct and explicit request strategy, i.e. by means of an imperative, is not represented in the analysed data.
} 
Direct strategies are illustrated below. Even though the infinitives (overt persuasion) follow request verbs, the analysed speech acts show an abundance of downtoners both in the Head act and Adjunct. Their perspective is mostly hearer-oriented.

(30) [explicit performative] Your Petitioners therefore most earnestly and humbly supplied your Excellency and the Colonial Government deeply to consider the wretchednefs which so nearly avails them. (Parker Party)

(31) [explicit performative] We have applied to you Sir, resting entirely on your Kindnefs, to inform and afsist us. (Whiley)

(32) [hedged performative] It is however a duty which I owe to her and to myself to request that you will do me the favor of an open order to the Naval Commifsion. (Willson)

(33) [hedged performative] I have therefore to entreat Your Lordship will be pleased to or$\underline{\text { der }} M^{\underline{r}}$ Denyson to terminate the protracted Businefs. (Jane Erith)

Both direct (34) and indirect (35) strategies may coincide with the infrequent (4 requests) impersonal perspective (e.g. resulting from passivisation):

(34) [scope stating] It would be very acceptable to me to be released from any Agreement or further intercourse with $\mathrm{M}^{\mathrm{r}}$. Parker. (Whiley)

[preparatory] Did it meet your approbation, it would be a kindnefs to $\mathrm{M}^{\mathrm{r}}$. Seton Mifs Coyle and myself to be permitted to land from this Vefsel. (Seton)

For the hearer-based perspective (which is the most common one; cf. Table 6 above), combined with a direct strategy, a hedge allows for hearer agency to stay implicit, which is an effect similar to impersonalisation, as in (36).

(36) [scope stance] I hope your Excellency will take my sake into consideration, to grant me a Pass. (Martinson)

The examples presented above show that unadorned (unmitigated) infinitives do not occur in requests. The need for overt persuasion inherent in the genre clashes with the need for humility as determined by the social inferiority of the petitioners to the addressee. Even though overt persuasion favours directness, the starkness and compression introduced by infinitives appears to violate the social constraints of the genre on the basis of which imposition needs to be minimised at all costs.

\section{Conclusion}

Although denunciation may not be seen as anything else than "a phenomenon of everyday life that exists in every society" (Fitzpatrick 1996: 832), the evidence for it as re- 
corded by the official letters of the 1820 British Settlers in the Cape Colony, South Africa, draws the attention of a linguist. Denunciation constitutes an exceptional communicative act in a fairly homogeneous corpus of request letters (i.e. petitions).

The social context of the 1820 British settlement of the Cape Colony might have prompted the petitioners to resorting to the means so far alien to the genre in order to make their petitions effective. These means might have been related to the persuasive aspect of the letters. The analysis presented above, however, demonstrates that denunciations, like petitions, are phrased in the language of humility. A closer look at the core functional move of the genre, the request, allows making a claim that the overt expression of persuasion entailed in the infinitives has not become a genre convention, while infinitives are not favoured as markers of persuasion. In other words, the illocutionary force of the request remains subject to the social constraint inherent in the asymmetrical relationship between the petitioners and the addressees. Despite the need for a greater effectiveness of the request communicated by the petition, the expression of persuasion is restrained by politeness concerns (cf. Brown and Levinson 1987).

Some textual features pertaining to persuasion were investigated in order to establish whether infinitives functioned as its overt markers (Biber 1988). Moreover, the study investigated which insights may be gained from a contextualised micro-analysis of infinitives found in openings, closings and requests in denunciation letters. In line with genre theory, it was assumed that requests are core functional moves in the petition (cf. Swales 1981, 1990). Therefore, some pragmatic aspects of requests were analysed in terms of Speech Act Theory (cf. Austin 1962; Blum-Kulka and Olshtain 1984; Warga 2004). Despite a clear preference for direct strategies of making requests and the fact that infinitives are normally present in them, the amount of mitigating devices (syntactic and Adjunct downtoners), places the infinitives as overt markers of persuasion somewhat in the background.

We have shown that corpus-based generalisations need to be thorougly contextualised, i.e. the correlation between infinitives and persuasion needs to be verified for every single item. Moreover, the study also demonstrated that Biber's generalisations concerning the syntactic and semantic features of infinitival heads (1988) do not sustain their validity in a contextualised analysis. In other words, Biber's claim as to the role of infinitives as markers of persuasion is not refuted in its entirety, but his claims as to the syntactic and semantic constraints on infinitival heads do not hold for the analysed corpus.

Despite the immense body of research conducted within historical corpus linguistics and the groundbreaking character of some of the findings, this paper advocates an alternative approach to the study of 19th century English(es). It is claimed that microscale synchronic analyses of individual contributions to the lingustic diversity of the period are an essential, though frequently neglected addition to the large-scale diachronic statistically oriented corpus investigations (such as e.g. Geisler 2003). Moreover, such micro-studies may be a necessity for an analysis of multiple varieties representative of the diverging English language of the period under consideration. 


\section{REFERENCES}

\section{PRIMARY SOURCES}

Colonial Office: Letters received from settlers. 1820-1825. CO136, 158, 178, 201, 223, 249 Cape Archives. (Colonial petitions.)

1820Settlers.com: 1819 letter transcriptions from the Public Record Office. (Settlement Scheme applications.)

\section{SECONDARY SOURCES}

Arnovick, L.K. 1999. Diachronic pragmatics. Seven case studies in English illocutionary development. Amsterdam: John Benjamins.

Austin, J.L. 1962. How to do things with words. Oxford: Oxford University Press.

Barton, D. (ed.). 2000. Letter writing as a social practice. Amsterdam: John Benjamins.

Beal, J.C. 2008. "Variation in Late Modern English: Making the best use of 'bad data"'. In: Fitzmaurice, S.M. and D. Minkova (eds.). 327-336.

Beal, J.C., K.P. Corrigan and H.L. Moisl (eds.). 2007. Creating and digitizing language corpora. (Vol. 2, Diachronic databases.) Basingstoke: Palgrave.

Bergen, L. van and D. Denison. 2007. “A corpus of late eighteenth-century prose”. In: Beal, J.C. et al. (eds.). 228-246.

Bergs, A.T. 2004. "Letters: A new approach to text typology". Journal of Historical Pragmatics 5(2). 207-227.

Bhatt, R. 2006. Covert modality in non-finite contexts. New York: Mouton de Gruyter.

Biber, D. 1988. Variation across speech and writing. Cambridge: Cambridge University Press.

Biber, D. 1995. Dimensions of register variation: A cross-linguistic comparison. Cambridge: Cambridge University Press.

Biber, D. 2006. University language: A corpus-based study of spoken and written registers. Amsterdam: John Benjamins.

Biber, D., S. Johansson, G. Leech, S. Conrad and E. Finegan. 1999. Longman grammar of spoken and written English. London: Pearson Education.

Biber, D., U. Connor and T.A. Upton (eds.). 2007. Discourse on the move: Using corpus analysis to describe discourse structure. Amsterdam: John Benjamins.

Bland, C. and M. Cross (eds.). 2004. Gender and politics in the age of letter writing 1750-2000. New York: Ashgate Publishing.

Blum-Kulka, S. and E. Olshtain. 1984. "Requests and apologies: A cross-cultural study of speech act realization patterns (CCSARP)". Applied Linguistics 5. 196-213.

Brant, C. 2004. "“The Tribunal of the Public': Eighteenth century letters and the politics of vindication". In: Bland, C. and M. Cross (eds.). 15-27.

Brown, P. and S.C. Levinson. 1987. Politeness: Some universals in language usage. Cambridge: Cambridge University Press.

Caldas-Coulthard, C.R. and M. Coulthard (eds.). 2003. Texts and practices. Readings in critical discourse analysis. London: Routledge.

Connelly, J. 1996. "The uses of Volksgemeinschaft: Letters to the NSDAP Kreisleitung Eisenach, 1939-1940". Journal of Modern History 68(4). 899-930.

Culpeper, J. and D. Archer. 2008. "Requests and directness in Early Modern English trial proceedings and play texts, 1640-1760". In: Jucker, A.H. and I. Taavitsainen (eds). 45-83.

Devitt, A.J. 2004. Writing genres. Carbondale: Southern Illinois University Press.

Dollinger, D. 2008. "Taking permissible shortcuts? Limited evidence, heuristic reasoning and the modal auxiliaries in early Canadian English”. In: Fitzmaurice, S.M. and D. Minkova (eds.). $357-385$. 
Dossena, M. and I. Tieken-Boon van Ostade (eds.). 2008. Studies in Late Modern English correspondence: Methodology and data. Bern: Peter Lang.

Dylewski, R. and P. Cap (eds.). 2004. History and present-day pragmatics of the English language. Łódź: Wydawnictwo Wyższej Szkoły Humanistycznej.

Elspass, S. 2007. "A twofold view 'from below': New perspectives on language histories and historical grammar". In: Elspass, S. et al. (eds.). 3-12.

Elspass, S., N. Langer, J. Scarloth and W. Vandenbussche (eds.). 2007. Germanic language histories 'from below' (1700-2000). Berlin: Walter de Gruyter.

Fairclough, N. 2003. "Technologisation of discourse". In: Caldas-Coulthard, C.R. and M. Coulthard (eds.). 71-83.

Fitzmaurice, S.M. and I. Taavitsainen (eds.). 2007. Methods in historical pragmatics. Berlin: Walter de Gruyter.

Fitzmaurice, S.M. and D. Minkova. 2008. "Introduction: Heuristics and evidence in studying the history of the English language". In: Fitzmaurice, S.M. and D. Minkova (eds.). 1-10.

Fitzmaurice, S.M. and D. Minkova (eds.). 2008. Studies in the history of the English language $I V$ : Empirical and analytical advances in the study of English language change. Berlin: Mouton de Gruyter.

Fitzpatrick, S. 1996. "Signals from below: Soviet letters of denunciation of the 1930s". Journal of Modern History 68(4). 831-866.

Fitzpatrick, S. and R. Gellately. 1996. "Introduction to the practices of denunciation in Modern European history". Journal of Modern History 68(4). 747-767.

Gellately, R. 1996. "Denunciations in twentieth-century Germany: Aspects of self-policing in the Third Reich and the German Democratic Republic". Journal of Modern History 68(4). 931967.

Gellately, R. 1997. "Denunciations and Nazi Germany: New insights and methodological problems". Historical Social Research 22(3/4). 228-239.

Geisler, C. 2003. “Gender-based variation in nineteenth-century English letter writing”. In: Leistyna, P. and C.F. Meyer (eds.). 87-106.

Halmari, H. and T. Virtanen (eds.). 2005. Persuasion across genres: A linguistic approach. Amsterdam: John Benjamins.

Hockly, H.E. 1948. The story of the British Settlers of 1820 in South Africa. Cape Town: Juta \& Co Ltd.

How, J.S. 2003. Epistolary spaces: English letter writing from the foundation of the Post Office to Richardson's Clarissa. Aldershot - Burlington: Ashgate Publishing.

Joshi, V. 2003. Gender and power in the Third Reich: Female denouncers and the Gestapo. New York: Palgrave Macmillan.

Jucker, A.H. and I. Taavitsainen (eds.). 2008. Speech acts in the history of English. Amsterdam: John Benjamins.

Kamalski, J., T. Sanders and L. Lentz. 2008. "Coherence marking, prior knowledge, and comprehension of informative and persuasive texts: sorting things out". Discourse Processes 45. 323-345.

Kerswill, P. 2006. "Migration and language". In: Mattheier, K.U. et al. (eds.). 2271-2284.

Knights, M. 2005. Representation and misrepresentation in Later Stuart Britain: Partisanship and political culture. Oxford: Oxford University Press.

Kohnen, T. 2007. "Text types and the methodology of diachronic speech act analysis". In: Fitzmaurice, S.M. and I. Taavitsainen (eds.). 139-166.

Kohnen, T. 2008. "Directives in Old English: Beyond politeness". In: Jucker, A.H. and I. Taavitsainen (eds.). 27-43. 
Kozlov, V. A. 1996. "Denunciation and its functions in Soviet governance: A study of denunciations and their bureaucratic handling from Soviet Police Archives, 1944-1953". Journal of Modern History 68(4). 867-898.

Kytö, M., M. Rydén and E. Smittenberg (eds.). 2006. Nineteenth-century English: Stability and change. Cambridge: Cambridge University Press.

Lakoff, R.T. 1981. "Persuasive discourse and ordinary conversation". In: Tannen, D. (ed.), Analysing discourse: Text and talk. Washington: Georgetown University Press. 25-42.

Lass, R. 1990. "How to do things with junk: Exaptation in language evolution". Journal of Linguistics 26(1). 79-109.

Lenoe, M.C. 1999. "Letter writing and the state. Reader correspondence with newspapers as a source for early Soviet history". Cahiers du Monde Russe 40(1-2). 139-170.

Leistyna, P. and C.F. Meyer (eds.). 2003. Corpus analysis: Language structure and language use. Amsterdam: Rodopi.

Lucas, C. 1996. "The theory and practice of denunciation in the French Revolution". Journal of Modern History 68(4). 768-785.

Mattheier, K., U. Ammon and P. Trudgill (eds.). 2006. Sociolinguistics/Soziolinguistik. An international handbook of the science of language and society (Vol. 3). Berlin: De Gruyter.

Mesthrie, R. and P. West. 1995. "Towards a grammar of Proto South African English". English World-Wide 16(1). 105-133.

Mirror of the Literature, Amusement and Instruction... 1835. 25 May.

Nevala, M. and M. Palander-Collin. 2005. "Introduction: Letters and letter writing”. European Journal of English Studies (Thematic issue on Letters and Letter Writing) 9(1). 1-7.

Nevalainen, T. 2004. "Letter writing: Introduction". Journal of Historical Pragmatics (Special Issue on Letter Writing) 5(2). 181-191.

Nevalainen, T. and H. Raumolin-Brunberg. 2003. Historical sociolinguistics: Language change in Tudor and Stuart England. London: Longman Pearson Education.

Nevalainen, T. and S-K. Tanskanen. 2007. (eds.). Letter writing. Amsterdam: John Benjamins.

Noy, C. 2002. "'You must go trek there': The persuasive genre of narration among Israeli backpackers". Narrative Inquiry 12(2). 261-290.

Nurmi, A. and M. Palander-Collin. 2008. "Letters as a text type: Interaction in writing". In: Dossena, M. and I. Tieken-Boon van Ostade (eds.). 21-49.

Nurmi, A., M. Nevala and M. Palander-Collin (eds.). 2009. The language of daily life in England (1400-1800). Amsterdam: John Benjamins.

Ott, S. 2006. "Good tongues, bad tongues: Denunciation, rumour and revenge in the French Basque Country, 1943-1945". History and Anthropology 17(1). 57-72.

Östman, J-O. 2005. "Persuasion as implicit anchoring. The case of collocations". In: Halmari, H. and T. Virtanen (eds.). 183-212.

Patterson, A. M. 1993. Reading between the lines. London: Routledge.

Searle, J.R. 1969. Speech Acts: An essay in the philosophy of language. Cambridge: Cambridge University Press.

Searle, J.R. 1979. Expression and meaning. Cambridge: Cambridge University Press.

Shagan, E.H. 2003. Popular politics and the English Reformation. Cambridge: Cambridge University Press.

Simons H.W., J. Morreale and B.E. Gronbeck. 2001. Persuasion in society. London: Sage Publications.

Swales, J.M. 1981. Aspects of article introductions. Birmingham: University of Aston.

Swales, J.M. 1990. Genre analysis: English in academic and research settings. Cambridge: Cambridge University Press. 
Swales, J. M. 2009. "Worlds of genre - metaphors of genre". In: Bazerman, C., A. Bonini and D. Figueiredo (eds.), Genre in a changing world. Indiana: Parlor Press. 3-16.

Taavitsainen, I. and A.H. Jucker. 2007. "Speech act verbs and speech acts in the history of English”. In: Fitzmaurice, S.M. and I. Taavitsainen (eds.). 107-138.

Taavitsainen, I. and A.H. Jucker. 2008. "Speech acts now and then: Towards a pragmatic history of English". In: Jucker, A.H. and I. Taavitsainen (eds). 1-25.

Tannen, D. (ed.). 1981. Analysing discourse: Text and talk. Washington: Georgetown University Press.

Tobias, J.J. 1979. Crime and Police in England, 1700-1900. New York: St. Martin's Press.

Virtanen, T. and H. Halmari. 2005. "Persuasion across genres: Emerging perspectives". In: Halmari, H. and T. Virtanen (eds.). 3-27.

Warga, M. 2004. Pragmatische Entwicklung der Fremdsprache. Der Sprechakt Aufforderung im Franzoesischen. Tübingen: Gunter Narr Verlag.

Westin, I. 2002. Language change in English newspaper editorials. Amsterdam: Rodopi.

Williams, B. 2001. "Letters of denunciation in the Lyon Region, 1940-1944". Historical Social Research 26(2/3). 136-152.

Włodarczyk, M. 2004."A costly compromise? - The 'bad' data problem in historical pragmatics”. In: Dylewski, R. and P. Cap (eds.). 75-110.

Włodarczyk, M. 2010.“Adaptive shifts: Identity and genre in the memorials of the 1820 Settlers in the Cape Colony". Werkwinkel: Journal of Low Countries and South African Studies 5(1). 47-72.

Wray, A. 2002. Formulaic language and the lexicon. Cambridge: Cambridge University Press.

Zaret, D. 1999. Origins of democratic culture: Printing, petitions, and the public sphere in Early-modern England. Princeton: Princeton University Press.

\section{Address correspondence to:}

Matylda Włodarczyk

School of English

Adam Mickiewicz University

Al. Niepodległości 4

61-874 Poznań

Poland

wmatylda@ifa.amu.edu.pl

\section{APPENDIX}

Fixed phrases including infinitives

\begin{tabular}{lcc}
\hline Word & Freq. & $\%$ \\
\hline I have the HONOR to & 8 & 4.91 \\
Your Lordship/Excellency will/would be PLEASED & 8 & 4.91 \\
I BEG to assure you/remain/leave to & 4 & 2.45 \\
Your Memorialist/Petitioner is BOUND to pray & 3 & 1.84 \\
\hline
\end{tabular}

